\title{
ANALISIS KEBUTUHAN KAPASITAS TAMPUNGAN EMBUNG DANAU ASAM DI KABUPATEN KOTAWARINGIN BARAT
}

\section{ANALYSIS OF REQUIREMENT CAPACITY STORAGE OF DANAU ASAM RESERVOIR IN WEST KOTAWARINGIN DISTRICT}

\author{
Asril Zevri \\ BWS Sumatera II Direktorat Jenderal Sumber Daya Air Kementerian PUPR \\ Jl. Jend Besar Dr. A. Nasution No. 30 Pkl. Mashur, Medan, Indonesia \\ *Correspondence Email: asrilevri19@gmail.com \\ Diterima 11 Mei 2021; Direvisi 02 Agustus 2021; Disetujui 14 Oktober 2021
}

\begin{abstract}
This study aims to analyze the requirement for the storage capacity of Danau Asam Reservoir as one of the solutions in increasing the availability of water to meet the needs of raw water due to population growth and climate change which is quite extreme. The study was conducted in the Danau Asam Reservoir with source of water from two watersheds that flow into the reservoir, namely the Lopo River Basin with a catchment area of $11.81 \mathrm{Km}^{2}$ and Kamat Bay with a catchment area of $12.42 \mathrm{Km}^{2}$ in Kotawaringin Lama District in the West Kotawaringin Regency. The method used is a quantitative approach based on a simulation of the water balance between the inflow and outflow. The inflow parameter is calculated based on 90\% probability reliable discharge using the FJ Mock method in two watersheds and the outflow parameter is based on the raw water demand discharge which is calculated based on the population growth rate. The result of the research indicate that the capacity of the Danau Asam Reservoir is 391,842.72 $\mathrm{m}^{3}$ to meet the raw water needs in Kotawaringin Lama District with a population of 35397 people.
\end{abstract}

Keywords: Drought, Raw Water, Storage, Kotawaringin Barat

\begin{abstract}
ABSTRAK
Penelitian bertujuan untuk menganalisis kebutuhan kapasitas tampungan Embung Danau Asam sebagai salah satu upaya solusi dalam meningkatkan ketersediaan air untuk memenuhi kebutuhan air baku akibat pertambahan jumlah penduduk dan perubahan iklim yang cukup ekstrem. Kajian dilakukan di Embung Danau Asam dengan sumber air berasal dari dua daerah aliran sungai yang mengalir ke embung yaitu Daerah Aliran Sungai Lopo dengan luas catchment area mencapai $11.81 \mathrm{Km}^{2}$ dan Teluk Kamat dengan luas catchment area mencapai $12.42 \mathrm{Km}^{2}$ yang berada di Kecamatan Kotawaringin Lama di wilayah Kabupaten Kotawaringin Barat. Metode yang dilakukan adalah pendekatan kuantitatif berdasarkan simulasi neraca air antara inflow dan outflow. Parameter inflow diperhitungkan berdasarkan debit andalan probabilitas 90\% dengan metode FJ Mock pada dua daerah aliran sungai dan parameter outflow diperhitungkan berdasarkan debit kebutuhan air baku yang diproyeksikan berdasarkan laju pertumbuhan penduduk. Hasil penelitian menunjukan besarnya kebutuhan kapasitas tampung Embung Danau Asam yaitu 391,842.72 $\mathrm{m}^{3}$ untuk memenuhi kebutuhan air baku di Kecamatan Kotawaringin Lama dengan jumlah penduduk 35397 Jiwa.
\end{abstract}

Kata Kunci: Kekeringan, Air Baku, Embung, Kotawaringin Barat 


\section{PENDAHULUAN}

Kabupaten Kotawaringin Barat merupakan salah satu wilayah yang berada di Provinsi Kalimantan Tengah. Wilayah Kabupaten Kotawaringin Barat terdiri dari enam kecamatan dengan total luas wilayah mencapai $10.759 \mathrm{Km}^{2}$ dan menjadi salah satu akses transportasi laut dalam mmobilisasi penduduk dan distirbusi barang logistic khususnya di Provinsi Kalimantan Tengah.

Pertambahan jumlah penduduk dalam kurun waktu 10 tahun terakhir meningkat cukup siginifikan dengan tingkat pertumbuhan jumlah penduduk yang mencapai $2.54 \%$ dalam kurun waktu 10 tahun (BPS Kab Kotawaringin Barat, 2021). Kondisi ini mengakibatkan jumlah kebutuhan air semakin meningkat sehingga berdampak terhadap meningkatnya kebutuhan air yang dikhawatirkan akan sulit dipenuhi oleh air yang tersedia khususnya apabila terjadi kekeringan.

Upaya atau solusi yang dilakukan pada saat ini salah satunya dengan membangun Embung Danau Asam yang memiliki multi fungsi salah satunya sebagai sumber air. Pembangunan Embung Danau Asam diharapkan dapat dimanfaatkan untuk kebutuhan air baku bagi masyarakat Kabupaten Kotawaringin Barat khususnya Kecamatan Kotawaringin Lama.

Lokasi penelitian berada di Embung Danau Asam di Kecamatan Kotawaringin Lama Kabupaten Kotawaringin Barat tepatnya di koordinat $2^{\circ} 29^{\prime} 24.67^{\prime \prime}$; $111^{\circ} 25^{\prime} 59.94 " E$. Sumber air berasal dari dua alur Sungai yaitu Sungai Lopo dan Teluk Kamat dengan luas Catchment Area Embung mencapai $24.23 \mathrm{Km}^{2}$ yang ditampilkan pada Gambar 1.

Penelitian bertujuan untuk merencanakan kebutuhan kapasitas tampungan Embung Danau Asam sebagai salah satu solusi dalam permasalahan kekeringan di Kabupaten Kotawaringin Barat.

Kekeringan pada dasarnya adalah keadaan kekurangan pasokan air pada suatu daerah untuk berbagai kegiatan, kelompok-kelompok dan sektor lingkungan dalam masa berkepanjangan, dapat mencapai beberapa bulan hingga tahunan (Darojati \& Barus, 2015) sedangkan (Raharjo, 2011) mendefinisikan kekeringan sebagai pengurangan kelembaban secara signifikan pada suatu periode tertentu yang tidak bersifat permanen.

Berdasarkan tipe dan karakteristiknya kekeringan dapat dibagi menjadi 3 (tiga); yaitu kekeringan meteorologis, kekeringan hidrologis dan kekeringan pertanian. Kekeringan meteorologis menunjukkan curah hujan dalam satu musim yang berada di bawah normal. Kekeringan ini menjadi indikasi awal munculnya bencana kekeringan. Kekeringan pertanian terjadi setelah kekeringan meteorologis, di mana kandungan air dalam tanah tidak mencukupi kebutuhan tanaman pada suatu periode tertentu dan cakupan wilayah yang luas. Kekeringan hidrologis terjadi apabila terdapat penurunan air di waduk, muka air sungai, danau dan muka air tanah secara alami (Lanen Van et al., 2016).

Embung adalah bangunan yang berfungsi menyimpan air hujan dalam suatu kolam dan kemudian dioperasikan selama musim kering untuk berbagai kebutuhan air suatu desa, yaitu rumah tangga, hewan ternak, kebun, dan lain-lain (Menteri Pekerjaan Umum dan Perumahan Rakyat Republik Indonesia, 2018). Klasifikasi embung dibagi menjadi 3 (tiga) jenis yaitu

a. Embung Besar

1. Tampungan antara $100.000 \mathrm{~m}^{3}$ $500.000 \mathrm{~m}^{3}$

2. Tubuh embung mempunyai tinggi maksimum $15 \mathrm{~m}$.

b. Embung Sedang

1. Daerah tadah hujan paling luas $100 \mathrm{ha}$,

2. Tampungan $10.000 \mathrm{~m}^{3}-100.000 \mathrm{~m}^{3}$,

3. Tubuh embung mempunyai tinggi maksimum $10 \mathrm{~m}$.

c. Embung Kecil

1. Tampungan $<10.000 \mathrm{~m}^{3}$,

2. Tubuh embung mempunyai tinggi maksimum $5 \mathrm{~m}$.

Kapasitas tampungan embung dihitung berdasarkan jumlah volume ketersediaan air dengan kebutuhan air. 


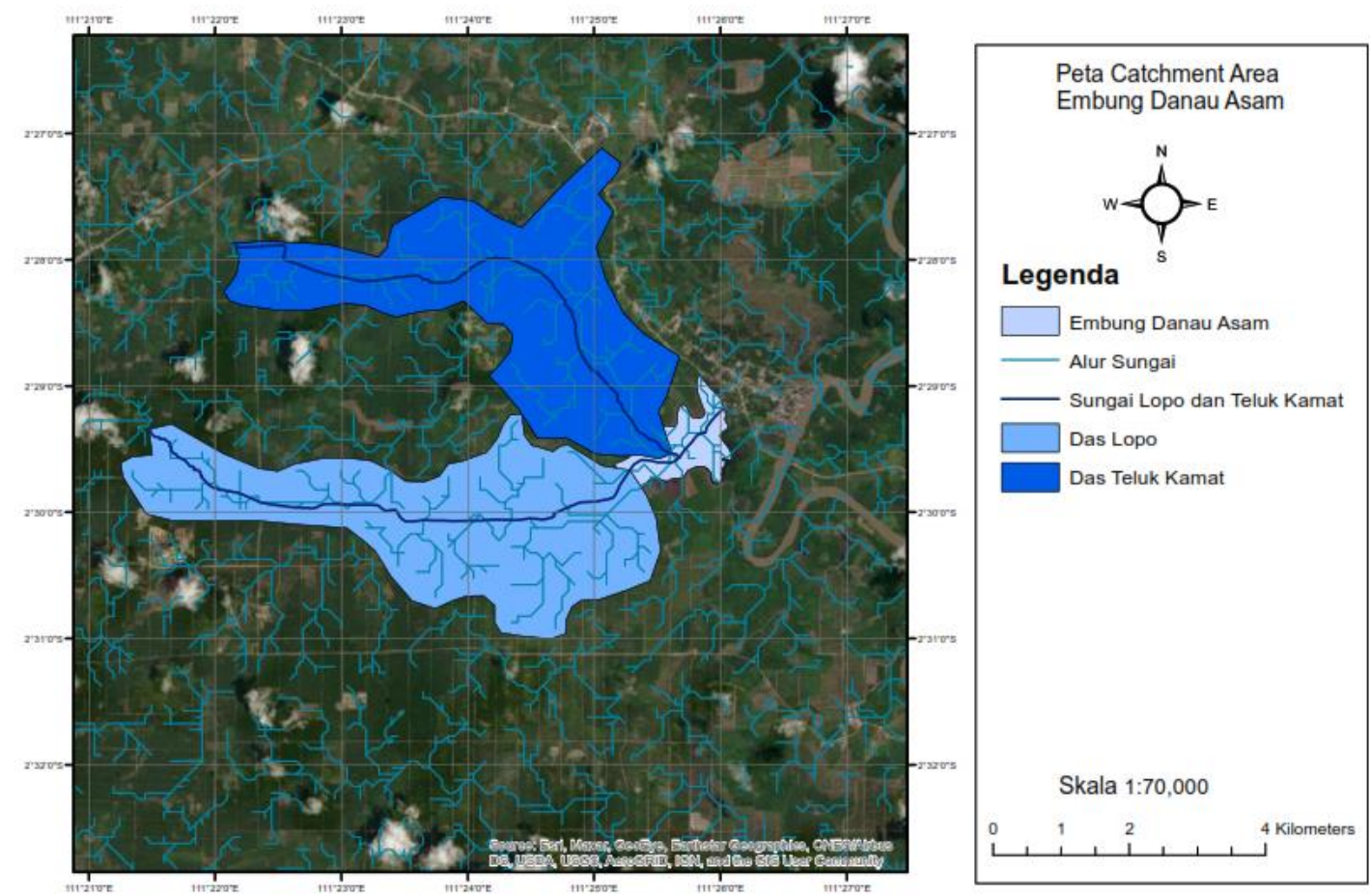

Gambar 1 Lokasi Embung Danau Asam

\section{METODOLOGI}

Metode penelitian yang dilakukan adalah pendekatan kuantitatif berdasarkan simulasi neraca air. Data penelitian yang digunakan adalah data sekunder yang diperoleh dari instansi terkait meliputi data curah hujan, luas DAS, dan klimatologi. Lingkup kegiatan dalam penelitian ini secara umum melakukan analisis hidrologi yang meliputi analisis inflow dan outflow dengan simulasi neraca air tampungan embung. Ruang lingkup kegiatan penelitian ditampilkan pada Gambar 2.

Simulasi antara kedua parameter tersebut dihitung dengan menggunakan model matematis seperti Metoda Ripple dan Sequent Peak Algoritma sering digunakan untuk menentukan berapa kapasitas tampung suatu waduk yang direncanakan dengan mensimulasikan hubungan antara besarnya ketersediaan air dan kebutuhan air (Bagiawan, 2013).

Debit kebutuhan air diperhitungan dengan menganalisis proyeksi jumlah penduduk dalam kurun waktu 25 tahun. Proyeksi jumlah penduduk diperhitungan dengan menganalisis tingkat pertumbuhan penduduk per tahun dengan periode waktu yang diperhitungkan kedepannya. Rumus yang digunakan dalam perhitungan proyeksi penduduk (Kristia et al., 2016) ditampilkan sebagai berikut.

$$
P n=P o x(1+i)^{n}
$$

Dengan

Pn = Jumlah Penduduk di tahun n (jiwa)

Po = Jumlah penduduk di tahun sebelumnya (jiwa

$\mathrm{i} \quad=$ Tingkat Pertumbuhan Penduduk (\%)

$\mathrm{n}$ = Tahun

Rumus debit kebutuhan air baku ditampilkan sebagai berikut.

Qairbaku = Pn x Standar kebutuhan air....(2)

Debit andalan diperhitungkan dengan menggunakan metode FJ Mock berdasarkan data curah hujan bulanan, evapotranspirasi, dan luas DAS (Zevri \& Isma, 2021). Secara umum tahapan perhitungan debit andalan dengan metode FJ Mock (Sitompul \& Efrida, 2018) ditampilkan sebagai berikut.

$$
\begin{aligned}
& \text { Qand = run off } \mathrm{x} \text { A } \\
& \text { Ro }=\mathrm{BF}+\text { Dro } \\
& \mathrm{BF}=\mathrm{I}-\mathrm{Ws} \text {. } \\
& \text { i }=\text { Koeff } \mathrm{i} \times \mathrm{Ws} \\
& \text { Ws =P-Eto+SMC. }
\end{aligned}
$$


Dengan

Qand = Debit Andalan $\left(\mathrm{m}^{3} /\right.$ det $)$

$\mathrm{A} \quad=$ Luas DAS $(\mathrm{Km} 2)$

Ro = Limpasan $(\mathrm{mm})$

WS = Water Storage $(\mathrm{mm})$

$\mathrm{P} \quad=$ Curah Hujan $(\mathrm{mm})$

Eto = Evapotranspirasi $(\mathrm{mm})$

I $\quad=$ Infiltrasi $(\mathrm{mm})$
BF $\quad=$ Base Flow $(\mathrm{mm})$

Simulasi kapasitas tampungan embung dianalisis dengan menggunakan pengembangan analisis deficit/numerik yang telah dianalisis untuk menentukan kelayakan dari perhitungan hubungan antara kapasitas tampung waduk/volume yang dibutuhkan dengan kelayakan pemenuhan kebutuhannya (McMahon, 2007).

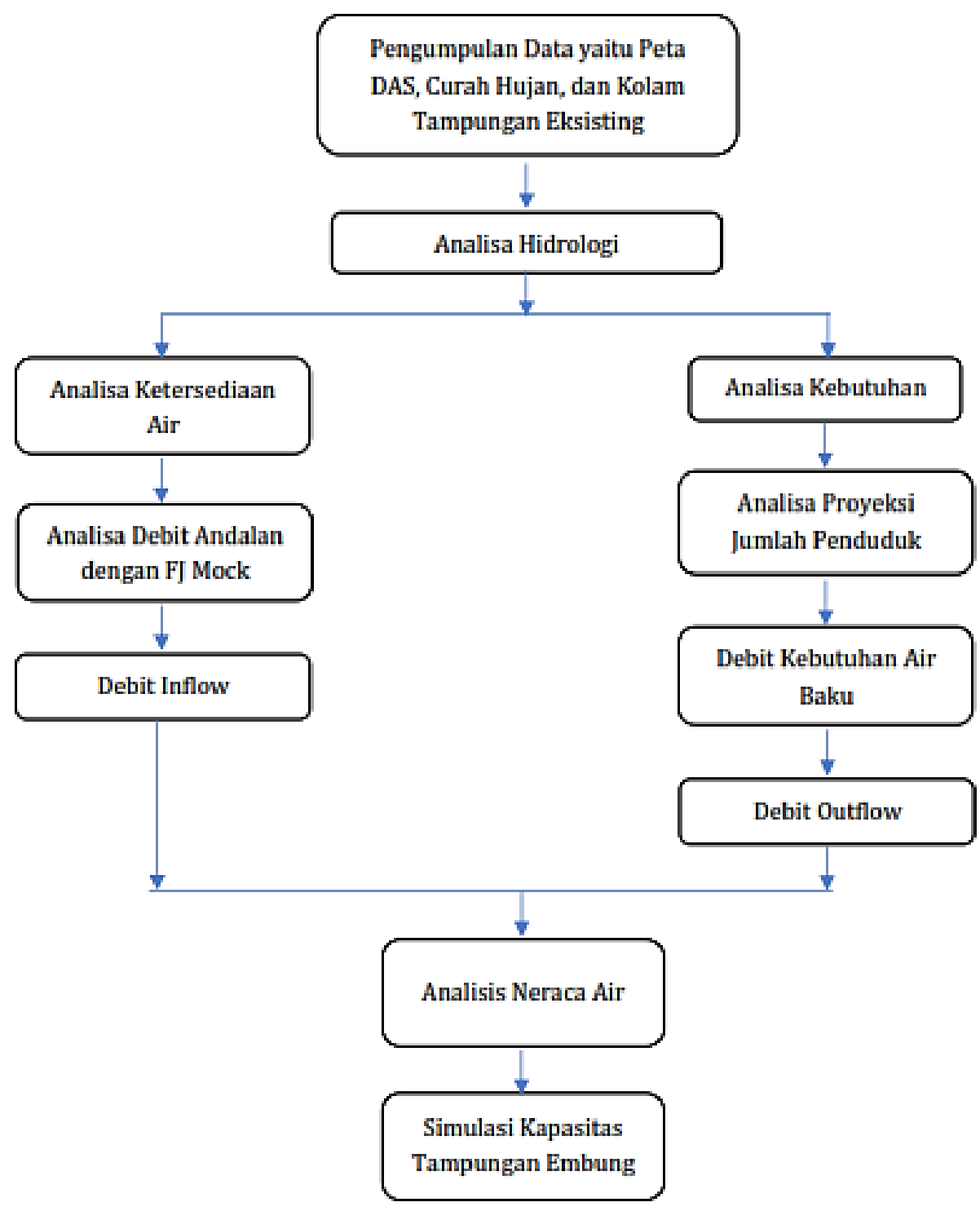

Gambar 2 Ruang Lingkup Kegiatan 
Formula ataupun rumus yang digunakan dalam analisis ini ditampilkan sebagai berikut:

\section{a. Analisis Numeric (Numeric Method)}

Metode simulasi analisis numeric dilakukan dalam penelitian ini dengan menganalisis neraca air antara ketersediaan air (inflow) pada lokasi pengembangan dan menganalisis besarnya kebutuhan air (outflow). Besarnya kapasitas tampung yang dibutuhkan ditentukan dari selisih antara volume outflow dikurangi inflow di mana volumenya maksimumnya merupakan kapasitas yang dibutuhkan untuk embung (Ginting, 2019). Persamaan kapasitas tampung ditentukan dengan persamaan.

$$
\mathrm{S}_{\mathrm{t}+1}=\mathrm{S}_{\mathrm{t}}+\mathrm{O}_{\mathrm{t}}-\mathrm{I}_{\mathrm{t}}
$$

Dengan

$$
\begin{aligned}
\mathrm{S}_{\mathrm{t}+1} \quad= & \text { storage pada saat } \mathrm{t}+1\left(\mathrm{~m}^{3}\right) \\
\mathrm{St} & =\text { storage pada saat } \mathrm{t}\left(\mathrm{m}^{3}\right) \\
\mathrm{O}_{\mathrm{t}} & =\text { total volume outflow yang keluar dari } \\
& \text { embung selama periode } \mathrm{t} \text { berupa } \\
& \text { pemakaian air domestik dan atau irigasi } \\
& \text { serta keluaran dari pelimpah embung }
\end{aligned}
$$

I $\quad=$ total volume debit inflow yang masuk ke waduk selama periode t (inflow ke embung berupa limpasan/runoff dan hujan)

$\mathrm{t} \quad=$ interval waktu yang digunakan (detik)

Penentuan kapasitas maksimum dari persamaan di atas diperoleh dengan menjumlahkan kumulatif storage akhir pada nilai kebutuhan air yang akan direncanakan.

\section{HASIL DAN PEMBAHASAN}

\section{Analisis Hidrologi}

Analisis hidrologi dalam penelitian ini bertujuan untuk menganalisis neraca air antara debit inflow dengan outflow. Debit inflow adalah debit ketersediaan air dengan outflow adalah debit kebutuhan air baku. Hasil analisis dijelaskan sebagai berikut

\section{Analisis Debit Kebutuhan Air Baku}

Analisis kebutuhan air baku dilakukan dengan memperhitungan jumlah penduduk yang dilayani di sekitar Embung. Wilayah yang menjadi layanan untuk memenuhi kebutuhan air baku yaitu Kecamatan Kotawaringin Lama. Jumlah penduduk di Kecamatan Kotawaringin Lama dalam kurun waktu 10 tahun terakhir ditampilkan pada Tabel 1.

Tabel 1 Jumlah Penduduk Kecamatan Kotawaringin Lama Dalam 10 Tahun Terakhir

\begin{tabular}{c|c|c}
\hline No & Tahun & $\begin{array}{c}\text { Jumlah Penduduk } \\
\text { (Jiwa) }\end{array}$ \\
\hline 1 & 2010 & 16796 \\
\hline 2 & 2011 & 17321 \\
\hline 3 & 2012 & 17777 \\
\hline 4 & 2013 & 18232 \\
\hline 5 & 2014 & 18695 \\
\hline 6 & 2015 & 19157 \\
\hline 7 & 2016 & 19615 \\
\hline 8 & 2017 & 20069 \\
\hline 9 & 2018 & 20522 \\
\hline 10 & 2019 & 20783 \\
\hline Sumber BPS Kab Kotawaringin Barat 2020
\end{tabular}

Tabel 2 Standar Kebutuhan Air

\begin{tabular}{c|c|c}
\hline \multirow{2}{*}{ Kategori Kota } & Jumlah Penduduk & $\begin{array}{c}\text { Standar } \\
\text { Kebutuhan Air }\end{array}$ \\
\cline { 2 - 3 } & (Jiwa) & (L/org/Hr) \\
\hline Metropolitan & $>1000000$ & $150-200$ \\
\hline Besar & $500000-1000000$ & $120-150$ \\
\hline Sedang & $100000-500000$ & $90-120$ \\
\hline Kecil & $20000-100000$ & $60-90$ \\
\hline Desa & $<20000$ & $40-60$ \\
\hline
\end{tabular}

Sumber: Dirjen Cipta Karya

Berdasarkan proyeksi jumlah penduduk 25 tahun dengan laju pertumbuhan (i) $=2.15 \%$ maka diperoleh jumlah penduduk mencapai 35397 Jiwa. Hasil debit kebutuhan air baku dengan mengacu kepada standar kebutuhan air 90 l/org/hr maka diperoleh debit kebutuhan air baku sebesar 0.037 $\mathrm{m}^{3} /$ det. 
Analisis Debit Andalan Bulanan Dengan Metode FJ Mock

Debit andalan diperhitungkan dengan metode FJ Mock berdasarkan data curah hujan bulanan, evapotranspirasi, dan luas DAS. Data yang digunakan dalam perhitungan debit andalan yaitu data curah hujan bulanan yang berada disekitar DAS Embung Danau Asam diperoleh dari Stasiun Curah Hujan BMKG Iskandar ditampilkan pada Tabel 3. Data curah hujan bulanan menunjukan bahwasanya nilai curah hujan berada di antara $0 \mathrm{~mm}$ /bulan s.d. $914 \mathrm{~mm} /$ bulan. Berdasarkan karakteristik curah hujan, kawasan Embung Danau Asam termasuk dalam kategori curah hujan yang tinggi. Hasil analisa debit andalan bulanan Embung Danau Asam ditampilkan berdasarkan total debit andalan DAS Lopo dan DAS Teluk Kamat ditampilkan pada Tabel 4 dan 5. Total debit andalan dengan probabilitas 90\% yang masuk mengalir ke Embung Danau Asam ditampilkan pada Tabel 6.

Hasil perhitungan menunjukan bahwasanya nilai debit andalan dengan probabilitas $90 \%$ untuk DAS Loko berada antara $0 \mathrm{~m}^{3} /$ det s.d $0.849 \mathrm{~m}^{3} /$ det dan DAS Teluk Kamat berada antara $0 \mathrm{~m}^{3} /$ det s.d $0.893 \mathrm{~m}^{3} /$ det. Besarnya debit andalan pada bulan tertentu cenderung mendekati $0 \mathrm{~m}^{3} /$ det sehingga perlu dilakukan usaha pembangunan embung untuk dapat menampung dan menjamin ketersediaan air dalam memenuhi kebutuhan air baku di Kecamatan Kotawaringin Lama.

Tabel 3 Data Curah Hujan Bulanan Selama 10 Tahun Terakhir di DAS Embung Danau Asam

\begin{tabular}{c|c|c|c|c|c|c|c|c|c|c|c|c}
\hline TAHUN & JAN & FEB & MAR & APR & MEI & JUN & JUL & AGU & SEP & OKT & NOV & DES \\
\hline 2011 & 164 & 79 & 288 & 230 & 101 & 17 & 54 & 26 & 0 & 72 & 162 & 233 \\
\hline 2012 & 87 & 194 & 262 & 220 & 110 & 15 & 27 & 0 & 63 & 57 & 383 & 378 \\
\hline 2013 & 142 & 204 & 168 & 358 & 217 & 27 & 217 & 320 & 224 & 217 & 397 & 294 \\
\hline 2014 & 72 & 206 & 303 & 241 & 227 & 148 & 74 & 21 & 21 & 0 & 203 & 407 \\
\hline 2015 & 220 & 160 & 202 & 293 & 236 & 59 & 88 & 0 & 0 & 0 & 88 & 267 \\
\hline 2016 & 315 & 325 & 286 & 249 & 325 & 113 & 260 & 128 & 336 & 332 & 330 & 452 \\
\hline 2017 & 417 & 419 & 276 & 417 & 342 & 128 & 419 & 339 & 327 & 435 & 312 & 541 \\
\hline 2018 & 222 & 344 & 400 & 272 & 383 & 107 & 0 & 0 & 346 & 313 & 606 & 211 \\
\hline 2019 & 460 & 986 & 587 & 642 & 554 & 229 & 0 & 0 & 4 & 37 & 93 & 234 \\
\hline 2020 & 914 & 516 & 707 & 395 & 293 & 597 & 492 & 325 & 353 & 554 & 591 & 265 \\
\hline
\end{tabular}

Sumber BMKG Iskandar

Tabel 4 Debit Andalan Bulanan Q90\% DAS Loko

\begin{tabular}{c|c|c|c|c|c|c|c|c|c|c|c|c}
\hline $\begin{array}{c}\text { Probabilitas } \\
(\%)\end{array}$ & Jan & Feb & Mar & Apr & May & Jun & Jul & Aug & Sep & Oct & Nov & Dec \\
\hline $10 \%$ & 5.351 & 4.626 & 3.025 & 2.847 & 2.340 & 2.629 & 2.089 & 1.284 & 1.400 & 2.319 & 2.639 & 2.238 \\
\hline $20 \%$ & 2.361 & 2.303 & 2.457 & 1.750 & 1.518 & 0.838 & 1.741 & 1.276 & 1.368 & 1.731 & 2.558 & 1.871 \\
\hline $30 \%$ & 2.065 & 1.788 & 1.583 & 1.671 & 1.367 & 0.493 & 1.003 & 1.259 & 1.349 & 1.250 & 1.636 & 1.638 \\
\hline $40 \%$ & 1.448 & 1.462 & 1.163 & 1.491 & 1.287 & 0.377 & 0.812 & 0.395 & 1.270 & 1.157 & 1.556 & 1.498 \\
\hline $50 \%$ & 0.836 & 1.334 & 1.061 & 1.181 & 1.147 & 0.363 & 0.249 & 0.058 & 0.820 & 0.764 & 1.312 & 1.112 \\
\hline $60 \%$ & 0.826 & 0.791 & 1.050 & 1.077 & 0.851 & 0.302 & 0.174 & 0.047 & 0.144 & 0.158 & 1.189 & 0.988 \\
\hline $70 \%$ & 0.480 & 0.779 & 0.984 & 0.970 & 0.812 & 0.135 & 0.119 & 0.000 & 0.047 & 0.125 & 0.753 & 0.955 \\
\hline $80 \%$ & 0.406 & 0.694 & 0.942 & 0.930 & 0.757 & 0.062 & 0.060 & 0.000 & 0.008 & 0.082 & 0.530 & 0.820 \\
\hline $90 \%$ & 0.081 & 0.533 & 0.685 & 0.849 & 0.321 & 0.039 & 0.000 & 0.000 & 0.000 & 0.000 & 0.211 & 0.820 \\
\hline 100\% & 0.071 & 0.187 & 0.542 & 0.835 & 0.252 & 0.033 & 0.000 & 0.000 & 0.000 & 0.000 & 0.207 & 0.742 \\
\hline
\end{tabular}

Sumber hasil perhitungan 
Tabel 5 Debit Andalan Blanan Q90\%DAS Teluk Kamat

\begin{tabular}{c|c|c|c|c|c|c|c|c|c|c|c|c}
\hline Probabilitas (\%) & Jan & Feb & Mar & Apr & May & Jun & Jul & Aug & Sep & Oct & Nov & Dec \\
\hline $10 \%$ & 5.704 & 4.944 & 3.228 & 3.026 & 2.501 & 2.815 & 2.221 & 1.374 & 1.518 & 2.482 & 2.828 & 2.410 \\
\hline $20 \%$ & 2.552 & 2.473 & 2.643 & 1.865 & 1.648 & 0.944 & 1.857 & 1.371 & 1.495 & 1.862 & 2.745 & 1.972 \\
\hline $30 \%$ & 2.275 & 1.925 & 1.718 & 1.782 & 1.478 & 0.525 & 1.053 & 1.312 & 1.427 & 1.326 & 1.736 & 1.731 \\
\hline $40 \%$ & 1.515 & 1.577 & 1.205 & 1.550 & 1.371 & 0.447 & 0.827 & 0.407 & 1.400 & 1.259 & 1.646 & 1.575 \\
\hline $50 \%$ & 0.972 & 1.422 & 1.131 & 1.231 & 1.239 & 0.388 & 0.250 & 0.061 & 0.868 & 0.790 & 1.394 & 1.160 \\
\hline $60 \%$ & 0.867 & 0.832 & 1.104 & 1.164 & 0.908 & 0.365 & 0.178 & 0.049 & 0.152 & 0.166 & 1.314 & 1.057 \\
\hline $70 \%$ & 0.505 & 0.812 & 1.077 & 1.019 & 0.865 & 0.142 & 0.125 & 0.000 & 0.050 & 0.132 & 0.798 & 1.056 \\
\hline $80 \%$ & 0.420 & 0.737 & 0.991 & 0.977 & 0.812 & 0.065 & 0.063 & 0.000 & 0.008 & 0.086 & 0.557 & 0.899 \\
\hline $90 \%$ & 0.086 & 0.566 & 0.723 & 0.893 & 0.344 & 0.040 & 0.000 & 0.000 & 0.000 & 0.000 & 0.254 & 0.863 \\
\hline $100 \%$ & 0.074 & 0.196 & 0.558 & 0.864 & 0.265 & 0.035 & 0.000 & 0.000 & 0.000 & 0.000 & 0.227 & 0.821 \\
\hline
\end{tabular}

Keterangan: Q90\%

Sumber hasil perhitungan

Tabel 6 Debit Andalan Bulanan Q90\% DAS Embung Danau Asam

\begin{tabular}{c|c|c|c|c|c|c|c|c|c|c|c|c}
\hline $\begin{array}{c}\text { Probabilitas } \\
(\%)\end{array}$ & Jan & Feb & Mar & Apr & May & Jun & Jul & Aug & Sep & Oct & Nov & Dec \\
\hline $10 \%$ & 5.704 & 4.944 & 3.228 & 3.026 & 2.501 & 2.815 & 2.221 & 1.374 & 1.518 & 2.482 & 2.828 & 2.410 \\
\hline $20 \%$ & 2.552 & 2.473 & 2.643 & 1.865 & 1.648 & 0.944 & 1.857 & 1.371 & 1.495 & 1.862 & 2.745 & 1.972 \\
\hline $30 \%$ & 2.275 & 1.925 & 1.718 & 1.782 & 1.478 & 0.525 & 1.053 & 1.312 & 1.427 & 1.326 & 1.736 & 1.731 \\
\hline $40 \%$ & 1.515 & 1.577 & 1.205 & 1.550 & 1.371 & 0.447 & 0.827 & 0.407 & 1.400 & 1.259 & 1.646 & 1.575 \\
\hline $50 \%$ & 0.972 & 1.422 & 1.131 & 1.231 & 1.239 & 0.388 & 0.250 & 0.061 & 0.868 & 0.790 & 1.394 & 1.160 \\
\hline $60 \%$ & 0.867 & 0.832 & 1.104 & 1.164 & 0.908 & 0.365 & 0.178 & 0.049 & 0.152 & 0.166 & 1.314 & 1.057 \\
\hline $70 \%$ & 0.505 & 0.812 & 1.077 & 1.019 & 0.865 & 0.142 & 0.125 & 0.000 & 0.050 & 0.132 & 0.798 & 1.056 \\
\hline $80 \%$ & 0.420 & 0.737 & 0.991 & 0.977 & 0.812 & 0.065 & 0.063 & 0.000 & 0.008 & 0.086 & 0.557 & 0.899 \\
\hline $90 \%$ & 0.086 & 0.566 & 0.723 & 0.893 & 0.344 & 0.040 & 0.000 & 0.000 & 0.000 & 0.000 & 0.254 & 0.863 \\
\hline $100 \%$ & 0.074 & 0.196 & 0.558 & 0.864 & 0.265 & 0.035 & 0.000 & 0.000 & 0.000 & 0.000 & 0.227 & 0.821 \\
\hline $\begin{array}{l}\text { Keterangan: } \\
\text { Sumber hasil perhitungan }\end{array}$ & & & & & & & & &
\end{tabular}

Analisis Simulasi Kapasitas Volume Tampungan Embung Danau Asam

Simulasi kapasitas tampungan Embung Danau Asam diperhitungkan dengan Metode Analitis Numerik yang dihitung berdasarkan neraca air antara debit inflow dan outflow dalam kurun waktu satu tahun. Debit inflow merupakan jumlah ketersediaan air dengan probabilitas 90\% dengan outflow adalah jumlah kebutuhan air baku dalam kurun waktu 25 tahun. Hasil volume kapasitas tampungan embung diperoleh dengan memperhitungkan selisih antara inflow dengan outflow tiap bulan yang disebut storage akhir. Besarnya volume storage akhir diperhitungkan selama satu tahun sehingga nilai volume yang paling kecil dalam satu tahun menjadi potensi volume kapasitas tampungan embung yang ditampillkan pada Tabel 7.

\section{Analisis Rencana Tinggi Tubuh Embung}

Rencana tinggi tubuh embung diperoleh berdasarkan hasil pengukuran topografi di dalam cakupan genangan embung yang terdiri dari elevasi, luas genangan, dan volume genangan (Krisnayanti et al., 2020). Elevasi kontur akan menghasilkan kumulatif luas genangan dan volume kumulatif genangan tampungan embung. Elevasi kontur dilakukan dengan selang $0.5 \mathrm{~m}$ dari dasar embung dengan tebing embung yang menjadi patokan paling tinggi dalam penentuan rencana tinggi tubuh embung. Peta elevasi kontur di sekitar embung ditampilkan pada Gambar 3. 
Tabel 7 Analisis Simulasi Kapasitas Tampungan Embung Danau Asam

\begin{tabular}{|c|c|c|c|c|c|c|c|c|}
\hline \multicolumn{9}{|c|}{ Simulasi Kapasitas Tampungan Embung Danau Asam } \\
\hline \multirow{3}{*}{ Bulan } & Jumlah & Storage & Ketersediaan & Ketersediaan & Kebutuhan & Kebutuhan & Storage & Kapasitas \\
\hline & Hari & Awal & $(\mathrm{m} 3 / \mathrm{s})$ & (m3) & Air Baku & Air Baku & Akhir & Tampungan \\
\hline & & & $90 \%$ & & $(\mathrm{~m} 3 / \mathrm{s})$ & (m3) & (m3) & (m3) \\
\hline Jan & 31.00 & & 0.167 & $447,043.50$ & 0.037 & $98,757.11$ & $348,286.39$ & \\
\hline Feb & 28.00 & & 1.099 & $2,658,076.66$ & 0.037 & $89,199.97$ & $2,568,876.69$ & \\
\hline Mar & 31.00 & & 1.407 & $3,768,874.39$ & 0.037 & $98,757.11$ & $3,670,117.28$ & \\
\hline Apr & 30.00 & & 1.743 & $4,516,663.11$ & 0.037 & $95,571.40$ & $4,421,091.72$ & \\
\hline May & 31.00 & & 0.665 & $1,780,960.12$ & 0.037 & $98,757.11$ & $1,682,203.01$ & \\
\hline Jun & 30.00 & & 0.079 & $204,743.50$ & 0.037 & $95,571.40$ & $109,172.10$ & \\
\hline Jul & 31.00 & & 0.000 & - & 0.037 & $98,757.11$ & $(98,757.11)$ & \\
\hline Aug & 31.00 & $(98,757.11)$ & 0.000 & - & 0.037 & $98,757.11$ & $(197,514.22)$ & \\
\hline Sep & 30.00 & $(197,514.22)$ & 0.000 & - & 0.037 & $95,571.40$ & $(293,085.62)$ & \\
\hline Oct & 31.00 & $(293,085.62)$ & 0.000 & - & 0.037 & $98,757.11$ & $(391,842.72)$ & $(391,842.72)$ \\
\hline Nov & 30.00 & $(391,842.72)$ & 0.465 & $1,205,383.01$ & 0.037 & $95,571.40$ & $717,968.89$ & \\
\hline Dec & 31.00 & & 1.683 & $4,507,178.74$ & 0.037 & $98,757.11$ & $4,408,421.64$ & \\
\hline Jan & 31.00 & & 0.167 & $447,043.50$ & 0.037 & $98,757.11$ & $348,286.39$ & \\
\hline Feb & 28.00 & & 1.099 & $2,658,076.66$ & 0.037 & $89,199.97$ & $2,568,876.69$ & \\
\hline Mar & 31.00 & & 1.407 & $3,768,874.39$ & 0.037 & $98,757.11$ & $3,670,117.28$ & \\
\hline Apr & 30.00 & & 1.743 & $4,516,663.11$ & 0.037 & $95,571.40$ & $4,421,091.72$ & \\
\hline May & 31.00 & & 0.665 & $1,780,960.12$ & 0.037 & $98,757.11$ & $1,682,203.01$ & \\
\hline Jun & 30.00 & & 0.079 & $204,743.50$ & 0.037 & $95,571.40$ & $109,172.10$ & \\
\hline Jul & 31.00 & & 0.000 & - & 0.037 & $98,757.11$ & $(98,757.11)$ & \\
\hline Aug & 31.00 & $(98,757.11)$ & 0.000 & - & 0.037 & $98,757.11$ & $(197,514.22)$ & \\
\hline Sep & 30.00 & $(197,514.22)$ & 0.000 & - & 0.037 & $95,571.40$ & $(293,085.62)$ & \\
\hline Oct & 31.00 & $(293,085.62)$ & 0.000 & - & 0.037 & $98,757.11$ & $(391,842.72)$ & $(391,842.72)$ \\
\hline
\end{tabular}


Tabel 7 Analisis Simulasi Kapasitas Tampungan Embung Danau Lanjutan

Simulasi Kapasitas Tampungan Embung Danau Asam

\begin{tabular}{|c|c|c|c|c|c|c|c|c|}
\hline Jumlah & Storage & Ketersediaan & Ketersediaan & Kebutuhan & Kebutuhan & Storage & Kapasitas & \\
\hline \multirow[t]{2}{*}{ Hari } & Awal & $(\mathrm{m} 3 / \mathrm{s})$ & (m3) & Air Baku & Air Baku & Akhir & Tampungan & \\
\hline & & $90 \%$ & & $(\mathrm{~m} 3 / \mathrm{s})$ & (m3) & (m3) & (m3) & \\
\hline Nov & 30.00 & $(391,842.72)$ & 0.465 & $1,205,383.01$ & 0.037 & $95,571.40$ & $717,968.89$ & \\
\hline Dec & 31.00 & $717,968.89$ & 1.683 & $4,507,178.74$ & 0.037 & $98,757.11$ & $5,126,390.52$ & \\
\hline Jan & 31.00 & & 0.167 & $447,043.50$ & 0.037 & $98,757.11$ & $348,286.39$ & \\
\hline Feb & 28.00 & & 1.099 & $2,658,076.66$ & 0.037 & $89,199.97$ & $2,568,876.69$ & \\
\hline Mar & 31.00 & & 1.407 & $3,768,874.39$ & 0.037 & $98,757.11$ & $3,670,117.28$ & \\
\hline Apr & 30.00 & & 1.743 & $4,516,663.11$ & 0.037 & $95,571.40$ & $4,421,091.72$ & \\
\hline May & 31.00 & & 0.665 & $1,780,960.12$ & 0.037 & $98,757.11$ & $1,682,203.01$ & \\
\hline Jun & 30.00 & & 0.079 & $204,743.50$ & 0.037 & $95,571.40$ & $109,172.10$ & \\
\hline Jul & 31.00 & & 0.000 & - & 0.037 & $98,757.11$ & $(98,757.11)$ & \\
\hline Aug & 31.00 & $(98,757.11)$ & 0.000 & - & 0.037 & $98,757.11$ & $(197,514.22)$ & \\
\hline Sep & 30.00 & $(197,514.22)$ & 0.000 & - & 0.037 & $95,571.40$ & $(293,085.62)$ & \\
\hline Oct & 31.00 & $(293,085.62)$ & 0.000 & - & 0.037 & $98,757.11$ & $(391,842.72)$ & $(391,842.72)$ \\
\hline Nov & 30.00 & $(391,842.72)$ & 0.465 & $1,205,383.01$ & 0.037 & $95,571.40$ & $717,968.89$ & \\
\hline Dec & 31.00 & $717,968.89$ & 1.683 & $4,507,178.74$ & 0.037 & $98,757.11$ & $5,126,390.52$ & \\
\hline
\end{tabular}

Sumber hasil perhitungan 
Tinggi tubuh embung dapat diperoleh dengan penyesuaian antara hasil simulasi kapasitas tampungan embung dengan volume kumulatif tampungan embung berdasarkan pengukuran topografi sehingga jika digambarkan akan membentuk grafik lengkung kapasitas embung (Narayana et al., 2015) yang ditampilkan pada Tabel 8 dan Gambar 4.

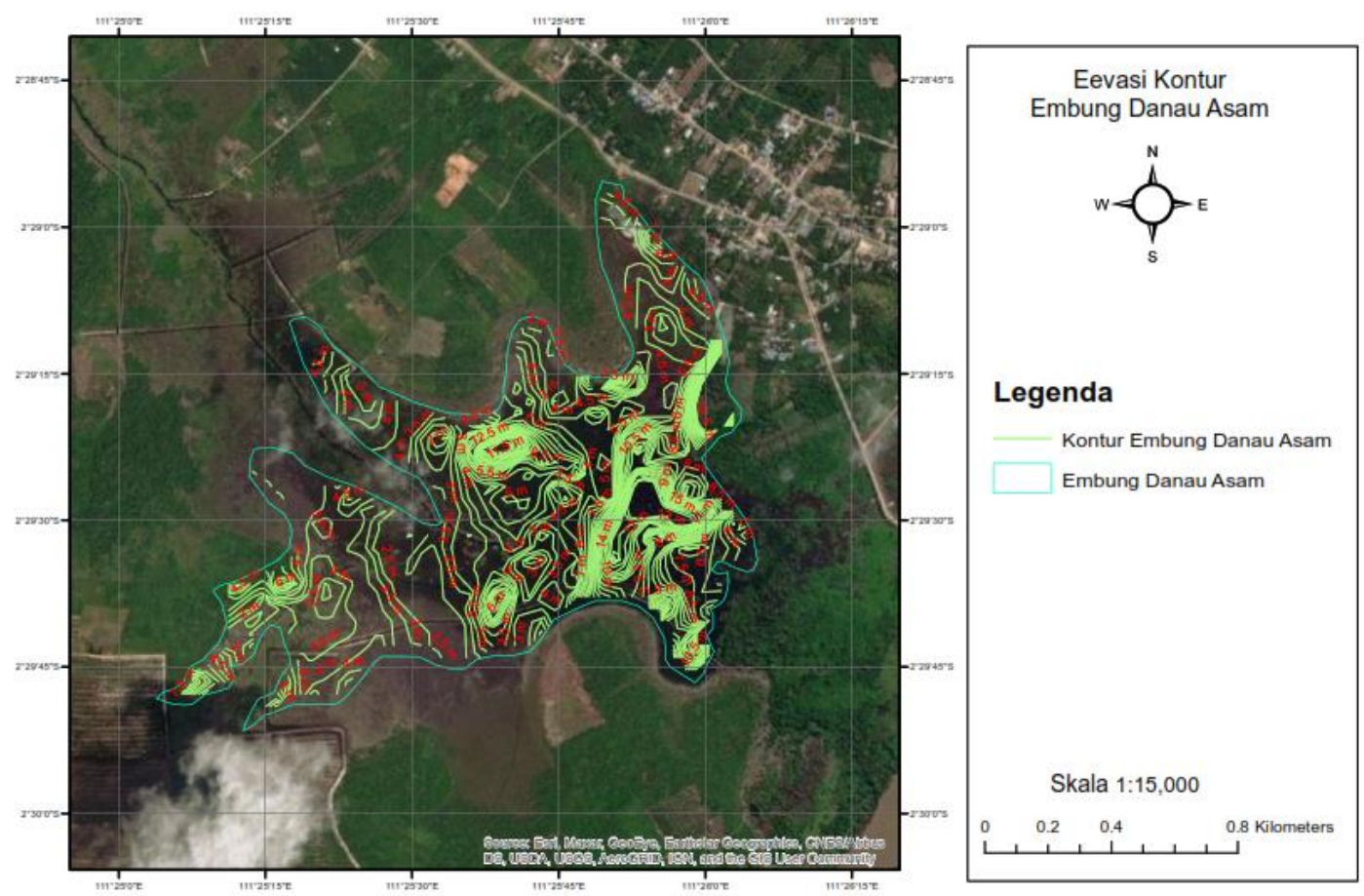

Gambar 3 Peta Elevasi Kontur Embung Danau Asam

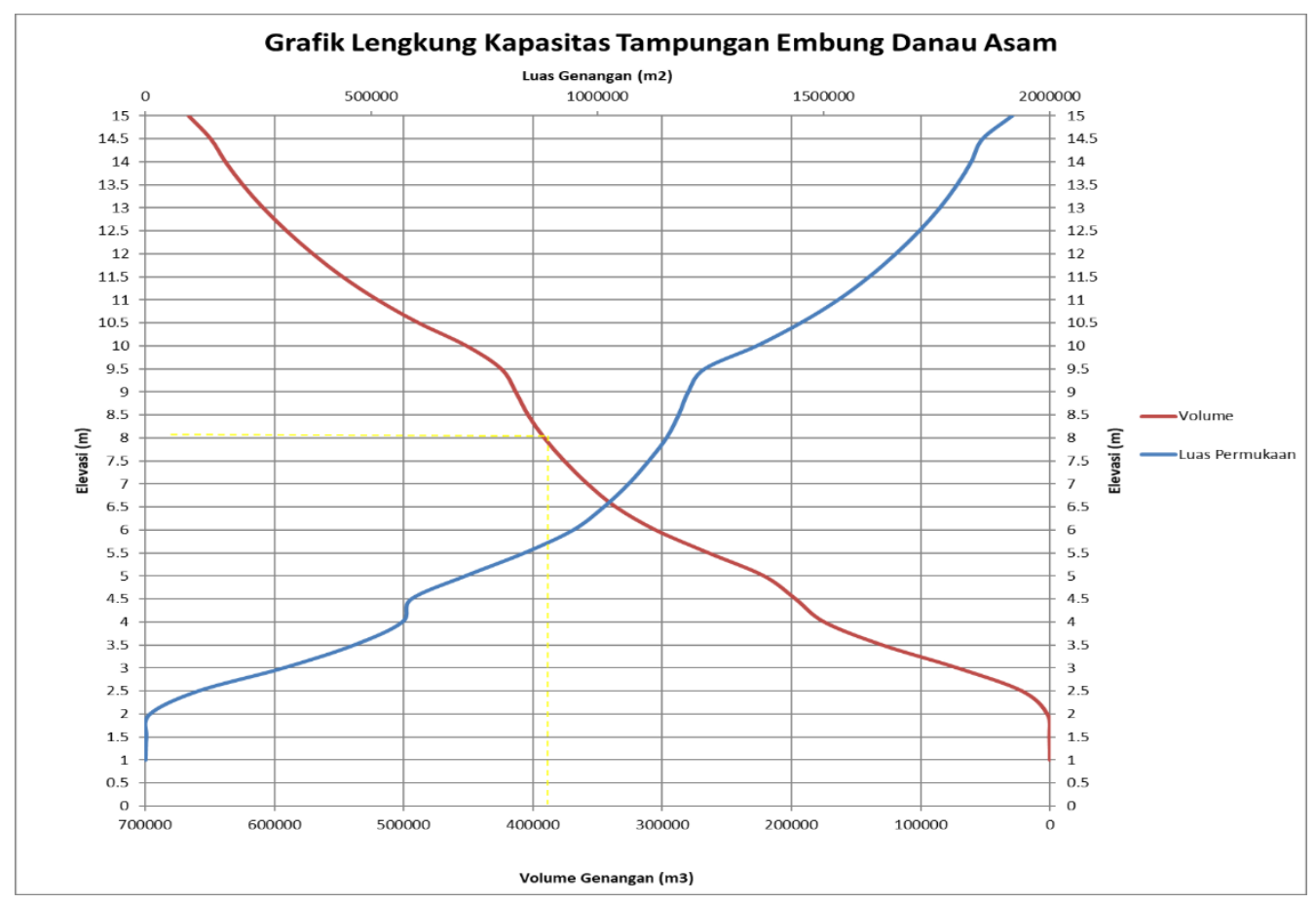

Gambar 4 Grafik Lengkung Kapasitas Tampungan Embung Danau Asam 
Tabel 8 Rencana Tinggi Tubuh Embung Danau Asam Berdasarkan Volume Kumulatif

\begin{tabular}{|c|c|c|c|c|c|}
\hline Elevasi & $\Delta \mathrm{h}$ & Luas $\left(\mathrm{m}^{2}\right)$ & Luas Kumulatif $\left(\mathrm{m}^{2}\right)$ & Volume $\left(\mathrm{m}^{3}\right)$ & Volume Kumulatif $\left(\mathrm{m}^{3}\right)$ \\
\hline 1 & 0 & 0 & 0 & 0 & 0 \\
\hline 1.5 & 0.5 & 1812.1 & 1812.1 & 344.585 & 344.59 \\
\hline 2 & 0.5 & 8217.4 & $10,029.50$ & 1780.402 & 2,124.99 \\
\hline 2.5 & 0.5 & 106670.7 & $116,700.20$ & 19504.008 & $21,629.00$ \\
\hline 3 & 0.5 & 188004.3 & $304,704.50$ & 49761.657 & $71,390.65$ \\
\hline 3.5 & 0.5 & 156615.2 & $461,319.70$ & 58311.811 & $129,702.46$ \\
\hline 4 & 0.5 & 106440 & $567,759.70$ & 44856.969 & $174,559.43$ \\
\hline 4.5 & 0.5 & 20324.9 & $588,084.60$ & 22202.585 & $196,762.02$ \\
\hline 5 & 0.5 & 118885.8 & $706,970.40$ & 24339.788 & $221,101.81$ \\
\hline 5.5 & 0.5 & 130437.7 & $837,408.10$ & 42796.647 & $263,898.45$ \\
\hline 6 & 0.5 & 108349.8 & $945,757.90$ & 41133.269 & $305,031.72$ \\
\hline 6.5 & 0.5 & 67567.6 & $1,013,325.50$ & 30719.239 & $335,750.96$ \\
\hline 7 & 0.5 & 54705 & $1,068,030.50$ & 21821.457 & $357,572.42$ \\
\hline 7.5 & 0.5 & 44658.7 & $1,112,689.20$ & 18037.343 & $375,609.76$ \\
\hline 8 & 0.5 & 39301.8 & $1,151,991.00$ & 15498.302 & $391,108.06$ \\
\hline 8.5 & 0.5 & 26898 & $1,178,889.00$ & 12560.022 & $403,668.09$ \\
\hline 9 & 0.5 & 21157.7 & $1,200,046.70$ & 9551.663 & $413,219.75$ \\
\hline 9.5 & 0.5 & 36097.5 & $1,236,144.20$ & 11103.364 & $424,323.11$ \\
\hline 10 & 0.5 & 115008 & $1,351,152.20$ & 26792.758 & $451,115.87$ \\
\hline 10.5 & 0.5 & 97438 & $1,448,590.20$ & 37080.910 & $488,196.78$ \\
\hline 11 & 0.5 & 82603 & $1,531,193.20$ & 31733.038 & $519,929.82$ \\
\hline 11.5 & 0.5 & 68654.2 & $1,599,847.40$ & 26979.008 & $546,908.83$ \\
\hline 12 & 0.5 & 58946 & $1,658,793.40$ & 23071.871 & $569,980.70$ \\
\hline 12.5 & 0.5 & 52201 & $1,710,994.40$ & 20360.198 & $590,340.89$ \\
\hline 13 & 0.5 & 45278 & $1,756,272.40$ & 18108.560 & $608,449.45$ \\
\hline 13.5 & 0.5 & 37998 & $1,794,270.40$ & 15763.622 & $624,213.08$ \\
\hline 14 & 0.5 & 31499.3 & $1,825,769.70$ & 13485.524 & $637,698.60$ \\
\hline 14.5 & 0.5 & 25124.3 & $1,850,894.00$ & 11354.729 & $649,053.33$ \\
\hline 15 & 0.5 & 65359.1 & $1,916,253.10$ & 17021.481 & $666,074.81$ \\
\hline
\end{tabular}

Keterangan: menunjukan Elevasi Tinggi Embung dengan Potensi Kapasitas Tampungan

Sumber hasil perhitungan

Hasil analisis volume kumulatif tampungan Embung Danau Asam yang disesuaikan dengan volume kapasitas tampungan embung yaitu $391,842.72 \mathrm{~m}^{3}$ diperoleh rencana tinggi tubuh embung mencapai $8 \mathrm{~m}$ dari dasar embung.

\section{KESIMPULAN}

Hasil penelitian menunjukan potensi ketersediaan air dengan probabilitas 90\% berada diantara $0 \mathrm{~m}^{3} /$ det hingga $1.743 \mathrm{~m}^{3} /$ det. Jumlah kebutuhan kapasitas tampungan Embung Danau Asam mencapai yaitu 391,842.72 $\mathrm{m}^{3}$.

\section{UCAPAN TERIMA KASIH}

Ucapan terima kasih dan penghargaan diberikan kepada semua pihak yang telah mendukung pembuatan artikel ini.

\section{DAFTAR PUSTAKA}

Bagiawan, A. (2013). Pengembangan areal layanan irigasi dari Bendung Perjaya - Sumatera Selatan dengan metode numerik dan "Sequent Peak" 8(1), 1-14.

BPS Kab Kotawaringin Barat. (2021). Laporan Jumlah Penduduk (pp. 2020-2022). 
Darojati, N. W., \& Barus, B. (2015). Pemantauan bahaya kekeringan di Kabupaten Indramayu. Jurnal IImu Tanah Dan Lingkungan, 17(2), 60. https://doi.org/10.29244/jitl.17.2.60-68

Ginting, S. (2019). Optimasi pemanfaatan air Embung Kasih untuk domestik dan irigasi tetes. Jurnal Irigasi, 13(1), https://doi.org/10.31028/ji.v13.i1.41-54

Krisnayanti, S. D., Hangae, E. E., Sir, M. . T., Mbauth, N. E., \& Damayanti, C. . (2020). Perencanaan Embung Wae Lerong untuk pemenuhan kebutuhan air irigasi di Daerah Irigasi Wae Lerong Ruteng Provinsi NTT. Jurnal Irigasi, 15(1), 15. https://doi.org/10.31028/ji.v15.i1.15-30

Kristia, M., Susilo, E, G., \& Romdania, Y. (2016). Perencanaan sistem penyediaan air baku di Kecamatan Punduh Pidada dan Kecamatan Padang Cermin, Kabupaten Pesawaran. Jurnal Rekayasa Sipil Dan Desain, 4(3), 333-344.

Lanen Van, H., Lahaa, G., Kingston, G, D., Gauster, T., Ionita, M., Vidal, P, J., \& Vlnas, R. (2016). Hydrology needed to manage droughts: the 2015 European case. Hydrological Processes, 30(17), 3097-3104. https://doi.org/10.1002/hyp.10838

McMahon, T. A. (2007). Revisiting reservoir storageyield relationships using a global streamflow database. Advances in Water Resources, 30(8), 1858-1872.

https://doi.org/10.1016/j.advwatres.2007.02.00 3
Menteri Pekerjaan Umum dan Perumahan Rakyat Republik Indonesia. (2018). Pedoman Pembangunan Embung Kecil dan Bangunan Penampung Air Lainnya di Desa. In Pedoman Pembangunan Embung Kecil dan Bangunan Penampung Air Lainnya di Desa.

Narayana, A., Khoirom, B., Kadir, A., \& Kurniani, D. (2015). Perencanaan Embung Tamanrejo Kecamatan Sukorejo, Kabupaten Kendal. Jurnal Karya Teknik Sipil, 4(1), 107-115.

Raharjo, P. D. (2011). Teknik penginderaan jauh dan sistem informasi geografis untuk identifikasi potensi kekeringan. MAKARA of Technology Series, 14(2), 97-105. https://doi.org/10.7454/mst.v14i2.700

Sitompul, M., \& Efrida, R. (2018). Evaluasi ketersediaan air DAS Deli terhadap kebutuhan air (Water Balanced). Jurnal Rekayasa Sipil (JRS-Unand), 14(2), 121. https://doi.org/10.25077/jrs.14.2.121-130.2018

Zevri, A., \& Isma, F. (2021). Studi keseimbangan air (Water Balanced) Daerah Aliran Sungai Asahan. Teras Jurnal, 11(1), 1-16. https://doi.org/: http://dx.doi.org/10.29103/tj.v11i1 